\title{
Persuasive and Informative Functions in Russian Advertising Discourse of Late Nineteenth Century
}

\author{
Larisa Anatolyevna Kochetova \\ Tamara Nikolayevna Tsynkerman \\ Department of English Philology Volgograd State University, Russia \\ Volgograd, 400062, Volgograd, 100 Universitetskii, Pr. \\ lakvolgu@mail.ru
}

Doi:10.5901/mjss.2015.v6n4s1p358

\begin{abstract}
Based on the corpus of advertisements compiled from Russian provincial newspapers of late nineteenth century the paper studies the balance between the informative and persuasive functions of Russian advertising discourse taking into consideration the following parameters: performative verbs and evaluative language. Three distributional patterns of performative verbs are defined: third person performatives; performatives expressed by an infinitive; canonical performatives. The study reveals that the functions of the patterns are contingent on the semantics of the verbs used. The first pattern with the verbal phrase 'donosit' do svedenia' relates to the informative function and employs negative politeness strategies to address the recipient of the advertising text with respect; the second pattern with an infinitive preceded by the verb 'vinuzhdat' 'to compel' in the finite form is used to minimize pressure on the recipient of the advertising text whenever a request is employed; on the contrary, the canonical performatives with the verbs 'sovetovat' (to advise), 'recomendovat' (to recommend) signals the authority of the advertiser. The distribution of the patterns with the performatives indicates that while the informative function is significant in the period under investigation the advertisers start influencing the recipients by emphasizing their knowledge and expertise, which is indicative of the persuasive function. The distribution of evaluative parts of speech shows that positively evaluated words are not frequent, the advertisers rarely praise goods or services and mainly emphasize a wide choice of products and reasonable prices.
\end{abstract}

Keywords: advertising discourse, diachrony, performative verb, adjective, persuasive function, informative function

\section{Introduction}

A field of diachronic discourse studies has been intensively developing in the last two decades (Brinton, 2001; Carroll, R., Hiltunen, R., Peikola, M., Skaffari, J.\& et al.,2003; Köhnen 2008; Jucker 2005). As Jucker (2005 p.9) points out it emerged on the linguistic landscape when historical linguists started to reach well beyond the sentence boundary and switched from studies of the language system to research of language-in-use that had occurred earlier in synchronic linguistics. Likewise, scholars engaged in discourse analysis, which had been commonly performed on a synchronic level, started to perceive communication as a dynamic phenomenon responsive to historical changes in the sociocultural context. Due to these two trends, discourse-oriented approach to texts that belong to the past periods has become one of the fastest-growing subfields at the cross-section of historical linguistics, text linguistics and discourse studies.

It is not surprising that scholars who adopt diachronic approach to discourse studies turn to English since vast empirical material on its use has been accumulated and stored in electronic archives and corpuses. However, other languages provide interesting material for the investigation of diachronic changes in language use. Research on the past stages of the Russian language has been limited and several reasons can be mentioned to account for this state. First of all, a discursive turn was adopted by Russian linguists a decade later than in European language studies and systemic approach to language had remained the mainstream linguistics until late twentieth century when first papers on discourse were written [Popova, 1995; Makarov, 2003]. Secondly, well-established disciplines in Russian linguistics such as stylistics with its major focus on literary texts still exert their influence and as a result even though the paper titles include the term 'discourse' they can be concentrated rather on stylistic features of texts than on discursive phenomena.

As for investigation of early texts in Russian linguistics there have been attempts to analyze individual genres that belong to the past historical periods but again they fell within the framework of diachronically-oriented stylistics that is aimed at exploring stylistic resources and genres in the course of a language historical development viewed as closely 
related to extra linguistic factors (see Kokorina (1992), Kozhina, Duskaeva (1993), Trosheva (1999), Solovjeva (1994)). Based on the statement by Kubrykova (1970) «any language change starts in language use», stylistic resources are regarded as the main source of language change arising from functional changes.

Despite the fact that most studies that adopt diachronic stylistic perspective investigate literary and scientific texts other genres are gradually coming into the orbit of research. Leonova (2013) investigated the genre of petition dated back to the seventeenth and early eighteenth centuries that is described as a syncretic one bearing features of petitions, formal statements, complaints, etc. It is stated that the term 'petition' (chelobitnaya) functioned as a general name for the petition or complaint (the petition itself ) and covered a variety of texts with various intentions of the addresser: a petition that notified the authorities (yavochnaya); a petition that informed the authorities about a planned crime (izvet); a petition admitting guilt and pleading for leniency; a petition stating that disputing parties had reached an agreement prior to court trial (mirovaya); a petition requesting for the trial postponement (otsrochnaya) etc. In fact, the author identifies the functional varieties of the genre and highlights linguistic features that mark the addressee's main intentions. The study, thus, lays ground for further study of the genre that might be aimed at revealing the processes of how the genre diversified and gave rise to new genres taking up and remixing features of their forerunner and generating a 'colony' of institutional genres. However, the study is restricted to the description of the taxonomy of genres that functioned in the institutional discourse in that particular period and does not investigate them from pragmatic perspective such as historical (im)politeness or conventionalised expression of deference. Besides, the study does not account for changes in users' preferences and fails to reach beyond the textual evidence to the dimension of verbal interaction.

As for diachronically-oriented stylistic approach to advertising, Mironova (2011) investigated advertising texts of the eighteenth and early twentieth century and identified several advertising genres that functioned at that period in Russian provincial newspapers such as catalogues, price lists, annotations, reviews, the publisher's address to the reader. The author identifies the second half of the nineteenth century as the period in advertising (the author does not use the term 'discourse') when a 'colony' (Bhatia 2004) of genres emerged among which a classified advertisement, a display advertisement, an advertising article, an advertising letter, an obituary, a drama, an expert testimony are distinguished. Though the study emphasizes the evolutionary nature of genre development it is limited mainly to enumeration of genres employed in provincial Russian advertising discourse and a description of the formal aspect of advertising texts. Thus, the study fails to trace the development of genre features, its pragmatic and functional aspects and almost completely neglects the historical context. Besides, it is not clear whether the genres that functioned in the eighteenth century remained in later periods or they were substituted by new genre forms. The study identifies the turn of the twentieth century as a turning point in Russian advertising discourse history when the advertising text had acquired the persuasive function. This conclusion stays in good agreement with research conducted on the history of English advertising discourse [see: Leech (1996), Vestergaard, Schröeder (1985), Myers (1997)] and allows us to put forward a hypothesis that advertising discourse might develop similar traits and show similar trends across cultures and its functions may have been evolving in close ways in different languages.

As this brief overview of papers dealing with historical perspective on discourse and genres shows that historical discourse studies in Russian linguistics still remain a rather neglected field, which can be attributed to the fact that the study of language-in-use has not been the mainstream linguistics in Russia where more emphasis has traditionally been given to language structure, stylistics and grammar.

The purpose of our study is to address the gap and investigate Russian advertising discourse of late nineteenth century as it was presented in newspapers published in the provincial press of Tsaritsyn, a town in the southern part of Russia, that was enjoying a certain prosperity in the period described related to the construction of a railroad in 1862 that promoted trade relations and economic growth in the town.

In comparison with the history of advertising, present-day Russian advertising language has received much more attention from scholars (Amiri \& Il'jasova, 2012; Goncharova, 2001). Few of these studies have been based on clearly defined corpora and they did not reveal the exact criteria by which the authors selected advertisements for their corpus. Drawing on the corpus of 200 advertisements from the newspapers that circulated in that period in the town of Tsaritsyn, namely Tsaritsinskiy Vestnik (1897-1917), Volzhsko-Donskoy Listok (1885-1901) and Tsaritsinskiy Listok Ob'yavleniy (1892-1897) we intend to identify and describe the balance between the informative and persuasive functions in provincial Russian advertising discourse of late nineteenth century and identify language means marking them. In contrast to the previous studies, we also will try to relate the obtained results to investigation of the relationship between participants in provincial Russian advertising discourse.

The first two newspapers were daily papers that published local news and news reprinted from papers published in the capital city of Moscow. The first and last pages of these newspapers were occupied by advertisements. The papers promoted themselves as an advertising medium that demonstrates that they were developing as commercial 
products. Tsaritsinskiy Listok Ob'yavleniy as the title suggests was developing as an advertising paper.

\section{Methodology}

In historical discourse studies scholars usually have to adapt tools they have taken from general discourse theory to the needs and demands of their own investigation. Methodological tools for the historical approach to the study of discourse in modern linguistic science are diverse which is due to several reasons among them one is likely to identify: 1) a variety of definitions for the key terms applied in the field as scholars have different views on such concepts as, for example, genre, text, and, discourse, every understanding offers a different set of tools to analyze language- in- use; 2) understanding of the main term 'discourse' may not be tied to the details of language but on ideas, issues and themes as they are expressed in talk and writing (Gee, 2011); 3) virtually every researcher faces a major challenge of accounting for language change drawing on data not observed directly but derived from various sources. Interpretation of discourse from historical perspective can be rather subjective because reading and interpretation of texts from the standpoint of the modern reader, and the reader who belonged to the period under investigation might be either largely or dramatically different. Finally, scholars can face lack of empirical research base as corpuses in many languages including Russian have recently started to be compiled and are mainly focused on contemporary texts.

The study will explore language means employed by advertisers that reflect text functions with respect to the social context. Most linguists agree that the main functions of advertisements are information and persuasion, with some scholars arguing that persuasion dominates information, for example Tanaka (1994). Advertisers might disguise their intention by presenting their advertisements as mere information or using some more subtle forms of persuasion. Persuasion does not have established explicit markers and is usually associated with certain linguistic forms such as imperatives, argumentation, evaluating language. The informative function may be indicated lexically by performative verbs, syntactically by the sentence type or the tense or mood of the verbs.

The purpose of the present paper is to investigate the advertising text functions with respect to the balance between the informative and persuasive functions in provincial Russian advertising discourse. The criteria for the analysis of the corpus are based on discussion of advertising language as language variety that according to the context of use can be expected to change with the social context so that linguistic change reflect historical changes. We identified information markers such as type of sentences, tense forms, lexical markers, namely performative verbs with the meaning 'to inform' and language units that have a definite persuasive function, such as the verbs sovetovat ('to advise'), rekomendovat' ('to recommend') and lexical units that convey evaluation. We defined three distributional patterns of performative verbs and analysed the distribution of the patterns in the corpus of texts with regard to the function performed. We compiled a list of evaluative language units and grouped them into clusters according to the type of referent they define to identify advertising techniques employed at that period in the provincial Russian newspapers. The corpus of the advertisements comprises 200 texts published in the period between 1885 - 1897. The limitations of the study are related to the fact that the analysis has not been assisted by computer programs because the material is not available in electronic forms and only printed copies of newspapers are available.

\section{Results}

The analysis revealed that the informative function is employed in all advertisements in our corpus. Most texts provide information concerning products or services offered, the informative function is marked by declarative sentences and indicative tense forms that dominate in the advertisements. As for quality and quantity of information presented in the advertisements is concerned, we have to point out that detailed information about the characteristics of the commodity or services is very seldom presented in the text. The advertisers usually mention 'a large assortment of' products without giving any particular details, for example, in Volzhsko-Donskoy Listok (01.02, 1885, №1):

\footnotetext{
"Торговля Закавказскихъ виноградныхъ винъ собственных виноградниковъ Бр. ПАПАЕВЫХъ (домъ К.И. Воронина, под Столичной гостиницей) доводитъ до съдънія своихъ покупателей, что в ихъ погребах имъется самъй разнообразный выборъ виноградных винъ послъднего розлива. Наши вина находятся так же и за Царищей напротив 2-й части у Якова Андреевича Зальцмана. -
}

Torgovlja Zakavkazskih vinogradnyh vin sobstvennyh vinogradnikov Br. PAPAEVYH (dom K.I. Voronina, pod Stolichnoj gostinicej) dovodit do svedenija svoih pokupatelej, chto $v$ ih pogrebah imeetsja samyj raznoobraznyj vybor vinogradnyh vin poslednego rozliva. Nashi vina nahodjatsja tak zhe i za Caricej naprotiv 2-j chasti u Jakova Andreevicha 


\title{
Zal'cmana.
}

The text informs the reader about a large assortment of wines sold by Brothers Papaevs, it mentions that the wines on sale are produced from their own vineyards and includes the addresses where these wines can be bought. However, the only piece of information the text contains is about the origin of wines (Zakavkazskie vinogradnye vina), no indication of prices or kinds of wine offered for sale is provided in the text.

Retailers often list their goods, as is the case in the following example where the advertiser enumerates a variety of goods available in her shop by dividing them into categories. The advertisement in Volzhsko-Donskoy Listok (01.11. 1885 , № 7) is rather long and has been reduced:

\author{
Магазинъ \\ Прасковьи Прохоровны Мордовкиной \\ Постоянно имъетъ: \\ Тульскія мъдныя издълія: самовары, кофейники, чайники, умывальники, тазы \\ Magazin \\ Praskov'i Prohorovny Mordovkinoj
}

Postojanno imeet:

Tul'skija mednyja izdelija: samovary, kofejniki, chajniki, umyval'niki, tazy [....].

The practice of presenting this general type of information was common and sometimes texts included general evaluation of the products, for example, in Tsaritzinskii vestnik (11. 30.1897):

Модный магазин М.Д. Свечина доводит до сведения г.г. покупателей в получении громадного выбора всевозможных суконных, триксовых и фатовых сезонных товаров новейших рисунков русских и заграничных фабрик [...]. - Modnyj magazin M.D. Svechina dovodit do svedenija g.g. pokupatelej v poluchenii gromadnogo vybora vsevozmozhnyh sukonnyh, triksovyh i fatovyh sezonnyh tovarov novejshih risunkov russkih i zagranichnyh fabric.

The advertisements informs the recipients that the Fashion Shop of M.D. Svechin's has received a huge assortment of various clothes by stressing that they are made to the latest fashion: "newest patterns from Russian and foreign factories".

The peculiar feature of most advertisements as is seen from the examples above is that the personal name of the producer/seller is put into the rheme position. Pragmatically this syntactic structure gives emphasis to the advertiser making him/her the communicative focus of the text that suggests that the advertiser personally guarantees good quality of goods provided and reasonable prices.

The analysis of the advertisements shows that nearly half of the texts in our corpus of advertisements from the period under investigation contain performative verbs, which are employed in various patterns. Typical performative verbs or phrases employed in the corpus are donosit' do svedeniya (inform), rekomendovat' (recommend), sovetovat' (advise), prosit' (ask for), ruchat'sja (guarantee), the occurrence of which is shown in Table 1. The table contains the number of occurrences of performative verbs or phrases in the advertisements investigated.

Table 1. The distribution of performative verbs in the corpus of advertisements

\begin{tabular}{|l|c|c|c|c|c|}
\hline The verb & donosit' do svedeniya (inform) & rekomendovat' (recommend) & sovetovat'(advise) & prosit' (ask for) & ruchat'sja(guarantee) \\
\hline Total number & 50 & 10 & 10 & 10 & 8 \\
\hline Percentage & $56,81 \%$ & $11,36 \%$ & $11,36 \%$ & $11,36 \%$ & $9,09 \%$ \\
\hline
\end{tabular}

As the numbers suggest the distribution of performative verbs in the advertisements show that the dominant one is the verb donosit' do svedeniya (inform) that indicates the informative function of the text. The rest of the verbs can be divided into two sub-groups: the first one includes the verbs rekomendovat' (recommend), sovetovat' (advise) that suggest the authority and indicate the superior position of the speaker who is assumed to possess expert knowledge or experience; the second one includes the verbs prosit' (ask for), ruchat'sja (guarantee) that indicate the lower position of the speaker who either does not have the right to give directions or instructions to the addressee or emphasizes his/her responsibility for the quality of products or services offered. The proportion of texts including neutral informative verbs is higher as compared to the number of texts that employ verbs indicating superior and lower position of the speaker in relation to the addresser of the advertising text that are distributed in nearly equal proportions.

We investigated explicit performative constructions in our corpus of advertisements and defined three distributional 
patterns that occur in the texts. We found that certain advertisements indicate the instantaneous performance of a speech act by using the canonical construction "(I) + speech act verb", in the next case explicit performatives in the corpus can be inscribed with third-person reference of different kinds or the performative verb can be used in the form of an infinitive preceded by a finite verb in the third person singular or plural. The study of Rütten (2013), who investigated Late Middle English administrative documents, concludes that performativity may be a gradable phenomenon and certain pragmatic contexts generate performative constructions which serve to (re)activate the speech act at some other point in time. The author points out that the canonical construction with a performative verb seems to be tied to oral communication and related forms with third-person reference give texts a more autonomous status. With regard to our corpus of advertisements it was found that patterns with the performative verb donosit' do svedeniya (inform) marking the informative function used either in the first person singular or plural and in the third person singular or plural are distributed equally in the corpus and comprise $45 \%$ of all instances. The verbs rekomendovat' (recommend), sovetovat' (advise) in the first person singular or plural that indicate the superior position of the advertiser comprise $34 \%$ of all the performative verbs in the corpus. The third distributional pattern where the action is performed by employing the construction with an infinitive preceded by the verb 'to compel'(vinuzhdat') occurs in $9 \%$ of all the cases. The results are presented in Table 2.

Table 2. The distribution of patterns with performative verbs

\begin{tabular}{|l|c|c|c|}
\hline & \multicolumn{3}{|c|}{ Types of distributional patterns } \\
\hline Verbs & 3rd person sing. or pl. & 1st person sing. or pl. & An infinitive + a finite verb \\
\hline donosit' do svedeniya (inform) & 20 & 20 & \\
\hline rekomendovat' (recommend) & & 10 & \\
\hline sovetovat' (advise) & & 20 & 8 \\
\hline prosit' (ask for) & & & 8 \\
\hline ruchat'sja (guarantee) & 10 & & \\
\hline Total & 30 & 50 & \\
\hline
\end{tabular}

The results allow us to conclude that trend to objective presentation of information in written discourse of advertising in provincial Russian newspapers was fairly strong in the period described. The advertisers employ strategies of negative politeness to avoid direct influence on the recipients. The patterns with performative verbs donosit' do svedeniya (inform), ruchat'sja (guarantee) used in the advertisements denote a long social distance between the advertiser and the recipient, who is free to make decisions on his/her future actions, heightening the aspect of politeness and certainly showing greater respect for the recipient by merely informing about the advertised product or service. The aspect of politeness receives more emphasis when performative verbs are modified by conventional polite formulae used in communication with addressees of higher social position such as (I) have the honour (imeyu chest'). While the pattern with an infinitive prosit' (ask for) that functions as a performative in combination with a finite verb vinuzhdat' emphasizes the humble position of the advertiser who is unwilling to put even the slightest pressure on the text recipient. The canonical pattern with performative verbs in the first person singular often employs lexical units that indicate a shorter social distance between the participants of advertising communication and intends to have a stronger persuasive effect on the addresser by being more persistent in their efforts to persuade potential customers to buy their goods or services.

The trend towards objectiveness that is the main feature of the information function in advertising texts is observed when a closer attention is given to the use of evaluative adjectives, adverbs and nouns with positive evaluation. The total number of words with positive evaluation irrespective of the part of speech in the corpus of 200 advertisements comprises 440 cases. Among them evaluative adjectives that describe a large assortment of goods on sale such as vsevozmozhnii (all possible kinds of), gromadnii (huge), bol'shoi (big) occur in 70 cases and are used attributively to the noun vibor (choice), thus, making 15, 9\% of all evaluative words. Another group of words that are related to prices occur in 50 cases $(11,3 \%)$ and includes such adjectives as deshevii (cheap) (4,5\%), umerennii (reasonable) (4,9\%), obschedostupnii (affordable) (2,2\%). The adjective of general positive evaluation horoshii (good) and its superlative form luchshii (best) occur in 2,2\% of cases. The positively evaluative compound noun dobrokachestvennost' that means "possessing good quality" occurs in $1 \%$ of texts. The advertisements sometimes use adjectives that are neutral but acquire a positive meaning in context. They are not frequent and include words indicating the origin of the products such as nemetskii 'German', angliiskii (English), zagranichnii (imported). The rest of the evaluative words accentuate that orders are dealt with timely and accurately with high precision and attention to detail. But their frequency is insignificant since they are used mainly in the advertisements for services. 


\section{Conclusion}

The analysis of the advertisements published in Russian provincial newspapers in late nineteenth century showed that the informative function was the dominant one and reflected the desire of advertisers to present their goods objectively without exercising too much pressure on the recipients. The use of patterns with performative verbs and comparatively rare presence of positively evaluative adjectives revealed that the informative function dominated in the advertising discourse under investigation. The distributional patterns of performative verbs also give indication of a trend toward unbiased representation of information. Third and first person forms of the verbal phrase 'donosit' do svedeniya' (to inform) that acts as a performative indicate the informative function and are related to negative politeness since they treat the recipient of the advertising text with respect; performatives expressed by an infinitive preceded by the verb 'vinuzhdat' 'to compel' in the finite form are characterized by even a higher degree of negative politeness and mitigate the pressure on the recipient caused by demand for an action that the verb "prosit" suggests.

The persuasive function is observed in the use of performatives in the first person singular and plural 'I (hereby) say' with specific lexical items such as the verbs 'sovetovat' 'to advise', 'rekomendovat" 'to recommend' that indicate that the status vector is directed down from the addresser to the recipient when the latter is treated as in need of advice or recommendation that signals the authority of the advertiser. The distribution of evaluative parts of speech indicate that the informative function prevails since positively evaluated words are not frequent, they rarely praise goods and mainly emphasize a wide choice and reasonable prices.

There is a certain difference in using evaluative language by retailers and producers. The first mainly rely on three major concepts such as 'a large assortment of goods', 'reasonable prices' and 'good quality', while the latter accentuated prompt and timely manufacture and delivery of goods. In general, advertisers avoided superlative adjectives being very cautious in their statements about the products and services. To account for this fact further study is needed that would investigate other newspapers and advertising language employed in them.

\section{Prospects}

Further research might be conducted to compare advertisements under investigation and advertising texts published in central newspapers in Moscow and St. Petersburg to bring out similarities and differences and outline trends in Russian advertising discourse development.

\section{Acknowledgement}

The research is funded by Russian Foundation for Humanities, the main contest, project 15-04-00134 "Historical Discourse Studies: Issues, Methodology and Prospects".

\section{References}

Amiri, L. P. \& Il'jasova S.V. (2010) Jazykovaja igra v reklame. In T.N. Kolokol'ceva (ed.). Reklamnyj diskurs i reklamnyj tekst : kollektivnaja monografija.. [Advertising Discourse and Advertising Text]. (pp. 201- 218). Volgograd: Izdatel'stvo VGPU «Peremena».

Bhatia, V. K. (2004) Worlds of Written Discourse. London : Continuum, 2004.

Brinton, L. J. (2001) Historical discourse analysis. In D. Schiffrin, D. Tannen \& H.E. Hamilton (Eds.). The Handbook of Discourse Analysis. (pp. 138-160). Oxford: Blackwell.

Carroll, R., Hiltunen, R., Peikola, M., Skaffari, J.\& et al.(2003) In Hiltunen R., Skaffari, J. (Eds.) Discourse Perspectives on English: Medieval to Modern [Pragmatics \& Beyond New Series 119]. (pp. 1 - 12). Amsterdam and Philadelphia: John Benjamins.

Gee, J.P. (2011) How to do discourse analysis: a toolkit. London: Routledge.

Goncharova, E. A. (2001) Persuazivnost' i sposoby ee jazykovoj realizacii v diskurse reklamy. (pp. 120 - 130). Studia Linguistica. SanktPeterburg: Trigon. Vyp. 10. Problemy teorii evropejskih jazykov.

Gunnarsson, B. (2001) Expressing criticism and evaluation during three centuries. Journal of Historical Pragmatics. Vol. 2 (1). pp. 115139.

Jucker, A.H. (2005) Mass media communication from the seventeenth to the twenty-first century In J.Toyota, J. Skaffari (eds). Opening Windows on Texts and Discourses of the Past. (pp. 39 - 52). Amsterdam: John Benjamin, 2005.

Köhnen, T. Historical text linguistics: Investigating language change in texts and genres, In H. Sauer, G. Waxenberger (Eds.) English Historical Linguistics 2008: Vol. 2: Words, Texts and Genres (pp. 166 - 187). John Benjamin Publishing Company.

Kokorina E.V. (1992) Stilisticheskie izmenenija v jazyke gazety:[Stylistic changes in the language of newspapers] Avtoref. dis. ... kand. 
filol. nauk. - Moscow.

Kozhina M.N. \& Duskaeva L.R. (1993) Lingvostilisticheskie izmenenija v russkoj gazete poslednego desjatiletija. [Lingvostylistic changes in the Russian newspaper of the latest decade]. (pp. 47 - 63). "Stylistyka-II". - Opole.

Kubryakova, E.S (1970) Jazyk kak istoricheski razvivajushheesja javlenie. In Serebrennikov B. A. (ed.) Obshhee jazykoznanie. Formy sustchestvovania, funkcii, istorija jazyka [Language as a historically developing phenomenon. In: General Linguistics. Fields of Linguistics, Language Functions and History]. (pp. 197-308). M.: Nauka.

Leech, G. N. (1966) English in Advertising. London: Longman.

Leonova J. J. (2013) Jazykovaja ob\#ektivacija pros'by v chelobitnyh XVII veka [Language Means in Request Speech Act in the Genre of Petition in the Seventeenth Century]: avtoreferat dissertacii ... kandidata filologicheskih nauk : 05.25.02. Volgograd.

Makarov, M. (2003) Obtschaya teoria discursa [Discourse Theory]. M.: Gnosis.

Mironova, A. A. (2011) Russkaja reklama v aspekte diahronicheskoj stilistiki [Russian Advertising Discourse from DiachronicallyOriented Stylistics Perspective]: avtoreferat dissertacii ... doktora filologicheskih nauk: 10.02.01 / Cheljabinsk.

Popova, E.A. (1995) Kul'turno-yazikovie harakteristiki politicheskogo diskursa: aftoref. ... k. philol. nauk. [Cultural and Linguistic Characteristics of political discourse].Volgograd.

Rütten, T. (2013) Formulae and performativity in Middle English documents. Journal of Historical Pragmatics. 14 (2), 285-304.

Solov'eva, G.I. (1994) Izmenenie stilja sovetskih rabot po politjekonomii v svjazi s vozdejstviemna nih jekstralingvisticheskih faktorov [Changes in the style of the Soviet newspapers on political economy related to extralinguistic factors] (pp. 78-96)// Funkcionirovanie jazyka v razlichnyh tipah teksta. - Perm'.

Tanaka, K. (1994) Advertising Language: A Pragmatic Approach to Advertisements in Britain and Japan. London : Routledge.

Toyota, J. (2005) Politeness as Distancing Device in the Passive and in Indefinite Pronouns. In J.Toyota \& J. Skaffari (Eds). Opening Windows on Texts and Discourses of the Past. (pp. 319-342). Amsterdam; Philadelphia, PA: John Benjamins Pub.

Trosheva, T.B. (1999) Formirovanie rassuzhdenija v processe razvitija nauchnogo stilja russkogo literaturnogo jazyka XVIII-XX vV. [The development of argumentation in the process of standard Russian scientific language evolution]. Perm'.

Vestergaard, T. \& Schröeder, K. (1985) The Language of Advertising. Oxford: Blackwell. 